\title{
Defermination of economic stocking rates for beef cattle grazing stargrass under two fertilizer levels
}

\author{
Mariano Antoni", Rafael Ramos', Américo Casas" \\ and Eugenio Marreros
}

\begin{abstract}
Two meaf production systems based on cattle grazing stargrass pastures under two fertilization levels were evaluated to determine which production system, stocking rate level, and selling time could be better used under different price scenarios to achieve maximum economic returns. Based on the findings of R. J. Jones and R. S. Sandland and other authors, it was assumed that the relationship between stocking rate and animal weight gain can be best represented by a simple linear model of the form $y=a-b x$ over $a$ wide range of stocking rates. To determine the equation parameters each system was grazed at three stocking rates and the straight line equation fitted at different periods. The price scenario prevailing at the conclusion of the study favored the utilization of the low fertilization system with a stocking rate close to 3.8 animals per hectare and selling the animals after 10 to 11 graxing months. This stocking rate should be lowered to 3.6 animals per hectare if a minimum finishing weight of $454 \mathrm{~kg}$ is required because of a $5 \%$ price discount for lighter animals. However, improvement on the price spread between animal purchase and selling price, or relatively sharp increase in meat price in relation to the fertilizer price could justify the utilization of the more capital intensive high fertilizer system. The selection of a particular production system and stocking rate should not be made independently of the current price levels since the latter will ultimately determine the success and failure of the system.
\end{abstract}

\section{RESUMEN}

Evaluación económica de dos sistemas de producción de carne en ganado apacentando yerba estrella en dos tasas de abonamiento

Se evaluaron dos sistemas de producción de carne basados en toros en pastoreo rotativo en pasturas de yerba Estrella bajo dos niveles de fertilización. Se determinó cuál sistema de producción, intensidad de pastoreo y época de venta era el mas apropiado para obtener los mejores ingresos pisibles bajo diferentes niveles de precios. Basado en los hallazgos de R. J. Jones y R. S. Sandland y otros investigadores, se presumió que la relación entre la carga animal y la ganancia en peso se puede representar por una

'Manuscript submitted to the Editorial Board 3 September 1991. This work was supported by a U.S. Department of Agriculture special grant in Tropical and Subtropical Agriculture, Grant no. 88-34135-3511.

${ }^{3}$ Associate Economist, Department of Agricultural Economies and Rural Sociology.

${ }^{3}$ Research Assistant, Department of Animal Industry.

${ }^{4}$ Research Assistant, Department of Animal Industry.

'Research Associate, Corozal Substation. 
función lineal de la forma $y=a-b x$ sobre una amplia gama de cargas animales. Para determinar los parámetros de la exuación se evaluaron tres cargas animales dentro de cada sistema y se ajustó la ecuación lineal en varios períodos de tiempo. Se encontró que bajo los niveles de precios vigentes a la conclusión del estudio la mejor alternativa de producción es la de usar el sistema que utiliza bajo abonamiento con una carga animal de aproximadamente 3.8 animales por hectárea y vender los animales después de estar entre 10 a 11 meses en pastoreo. Esta carga animal debe reducirse a 3.6 animales por hectárea si es obligatorio que los animales alcancen un peso final de $\mathbf{4 5 4} \mathrm{kg}$. Una disminución en el diferencial entre el precio de compra inicial y el precio de venta de los animales, o un aumento en el precio de la carne con relación al precio del abono, podrían, sin embargo, justificar la utilización del sistema de fertilización intensiva.

\section{INTRODUCTION}

The evaluation of meat production systems based on cattle grazing tropical grass pastures under different fertilization levels and stocking rates has been the subject of frequent studies in Puerto Rico. The most frequent approach to develop stocking rate-fertilizer level recommendations has been to compare up to three levels of fertilizer applications, each associated with a particular stocking rate thought to be optimum, and to select the best performer among them $(1,3)$. Since under these systems only one stocking rate is associated with each fertilizer level, the results of these studies cannot be used for the estimation of a stocking rate-meat production function to be used for the determination of economic stocking rate levels under different price scenarios.

This study evaluates the performance of two fertilizer-stocking rate beef production systems to be used under different price scenarios to achieve maximum economic returns. In both systems animals grazed pastures of stargrass (Cynodon nlemfuensis Vanderyst var. nlemfuensis), which is one of the most widely planted grasses in the humid region of Puerto Rico (4). The first system is based on a fertilization level of 3,025 kg/ha of 15-5-10 fertilizer. Caro-Costas et al. (1) found that stargrass pastures responded, in terms of beef production per hectare, to applications of up to $4,480 \mathrm{~kg} / \mathrm{ha}$ of $15-5-10$ fertilizer. They pointed out, however, that for the prices of beef and fertilizer prevailing at the time, only the gain in weight resulting from increasing fertilization from 1,972 to $3,136 \mathrm{~kg} / \mathrm{ha}$ would be economical. This system is within the economic range suggested in the above study. Caro Costas et al. (2) also reported that low cut stargrass responded sharply to up to $450 \mathrm{~kg} / \mathrm{ha}$ of nitrogen when harvested every 30 days (the nitrogen equivalent of using 3000 $\mathrm{kg} / \mathrm{ha}$ of 15-5-10 fertilizer), and that thereafter, and up to $900 \mathrm{~kg} / \mathrm{ha}$ of nitrogen, the response was small but persistent. It is presumed that, if for a given price structure, it were found that it pays to use a fertilizer intensive technology, it would be safe to fertilize up to $450 \mathrm{~kg} / \mathrm{ha}$ of nitrogen since, as reported by Caro-Costas (2), the stargrass response 
to fertilization up to this level was very high. The second system is based on a fertilization level of $890 \mathrm{~kg} / \mathrm{ha}$ of $15-5-10$ fertilizer. If the meat-fertilizer price ratio is low, then the farmer would use the system that involves a low fertilization level, and choose the most favorable stocking rate for it. If the meat-fertilizer price ratio is high enough to justify a high fertilization level, then the farmer will have an alternative system to fertilize up to, or close to, the level at which the grass response to increasing amounts of fertilization starts to decline.

This study is based on the findings of R. J. Jones and R. S. Sandland (7) and other authors $(10,11)$ who have studied the relationship between stocking rate (animals per hectare) and animal weight gain and have found that the relationship is linear over a wide range of stocking rates. Jones and Sandland found that the relationship between gain per animal and stocking rate remains linear over the range of 0.18 to 2.0 times the optimum stocking rate. They gathered data from 33 different pastures, fitted individual linear regression equations to the data, and found that all relations were linear $(r=-0.85$ to -0.999$)$. Since many studies compared only three stocking rates, they combined the data to see if they could find any significant departure from linearity but found none. They suggested that since the relation was linear over a wide range of stocking rates, only two rates (with replication) may be adequate for the determination of the function, and these would not have to span the optimum stocking rate to predict gain at optimum stocking rate.

The present study utilizes three stocking rates, without replications, for the determination of the gain per animal production function. The stocking rate spread was restricted so as to insure that the fitting of the equation would be within the linear response region to avoid any significant departure from linearity. The higher stocking rate was not set too high to avoid damage to the pastures, and to avoid being too far from the economic region since the economic optimum should be with a stocking rate lower than the one for maximum production per area (9).

\section{MATERIALS AND METHODS}

This study was conducted at the Corozal substation of the Agricultural Experiment Station located at an elevation of about $200 \mathrm{~m}$. The environmental conditions are typical of the humid mountain regions of the island. The annual rainfall during the experiment period (January to December 1989) was $1865 \mathrm{~mm}$, which was very close to the annual mean rainfall of $1854 \mathrm{~mm}$ for the station (8). The soil is a deep, red, acid, moderately well drained Corozal Clay (Ultisol) (12).

An area of 13.6 hectares planted to stargrass was subdivided into 24 paddocks to accommodate six treatments and four pasture replicates. Forty-eight young bulls ranked according to weight and breed were ran- 
domly distributed among the six treatments. The experimental animals used were of the Charbray and Brahman breeds, and 50\% crossbred Senepol with Holstein and Charbray. There were no replications of the treatments. The paddocks, however, were distributed according to a randomized block design with four pasture replications. The animals grazed the pastures on a rotational scheme according to pasture availability.

The study began 29 December 1988 when the animals were weighed, treated for parasites and distributed to the various treatments. Their initial mean weight was $250 \mathrm{~kg}$ (range 200 to 292). Mineral salts were offered in all cases. On 26 January 1989, i.e., 29 days after beginning the animal trial, a correction was made in the two higher stocking rate treatments. An evaluation of the initial conditions led to the conclusion that the original stocking rates would have caused an unnecessarily high grazing pressure by the time the animals reach 360 to $400 \mathrm{~kg}$. Since at the beginning of the field trial the pasture was plentiful and the animals were small, thus resulting in a low grazing pressure, it was assumed that in the long run the effect of this correction would be negligible.

The stocking rate treatments selected ror the adjustment of a meat production function for the low fertilization level system (System A), which consisted of pastures fertilized at the rate of $890 \mathrm{~kg} / \mathrm{ha}$ of $15-5-10$ fertilizer applied annually in two equal applications, were as follows:

T-1 :Animals grazing at a stocking rate of 1.23 per hectare

T-2 :Animals grazing at a stocking rate of 2.47 per hectare

T-3 :Animals grazing at a stocking rate of 3.71 per hectare

The stocking rate treatments selected for the high fertilization level system (System B), which consisted of pastures fertilized at a rate of $3,026 \mathrm{~kg} / \mathrm{ha}$ of $15-5-10$ fertilizer applied annually in four equal applications, were as follows:

T-4 :Animals grazing at a stocking rate of 3.71 per hectare

T-5 :Animals grazing at a stocking rate of 4.94 per hectare

T-6 :Animals grazing at a stocking rate of 6.79 per hectare

There were six animals per treatment for T-1 to T-4; 8 and 11 animals in T-5 and T-6, respectively. The number of animals for the latter treatment was higher because it was necessary to keep the paddock area to a minimum of 0.4 hectare ( 1 acre) or 1.6 ha/treatment) to avoid using too small pasture areas. Pasture areas for T-1 and T-2 were set at 1.21 ha and 0.61 ha per paddock, respectively, to maintain a minimum of 6 animals per treatment. The animals were weighed at about 1-month intervals after a 15- to 18-hour stay in confinement without feed or water. 
J. Agric. Uniw. P.R. vol. 76, NO. 3-4, JULy/OCTOBER, 1992135

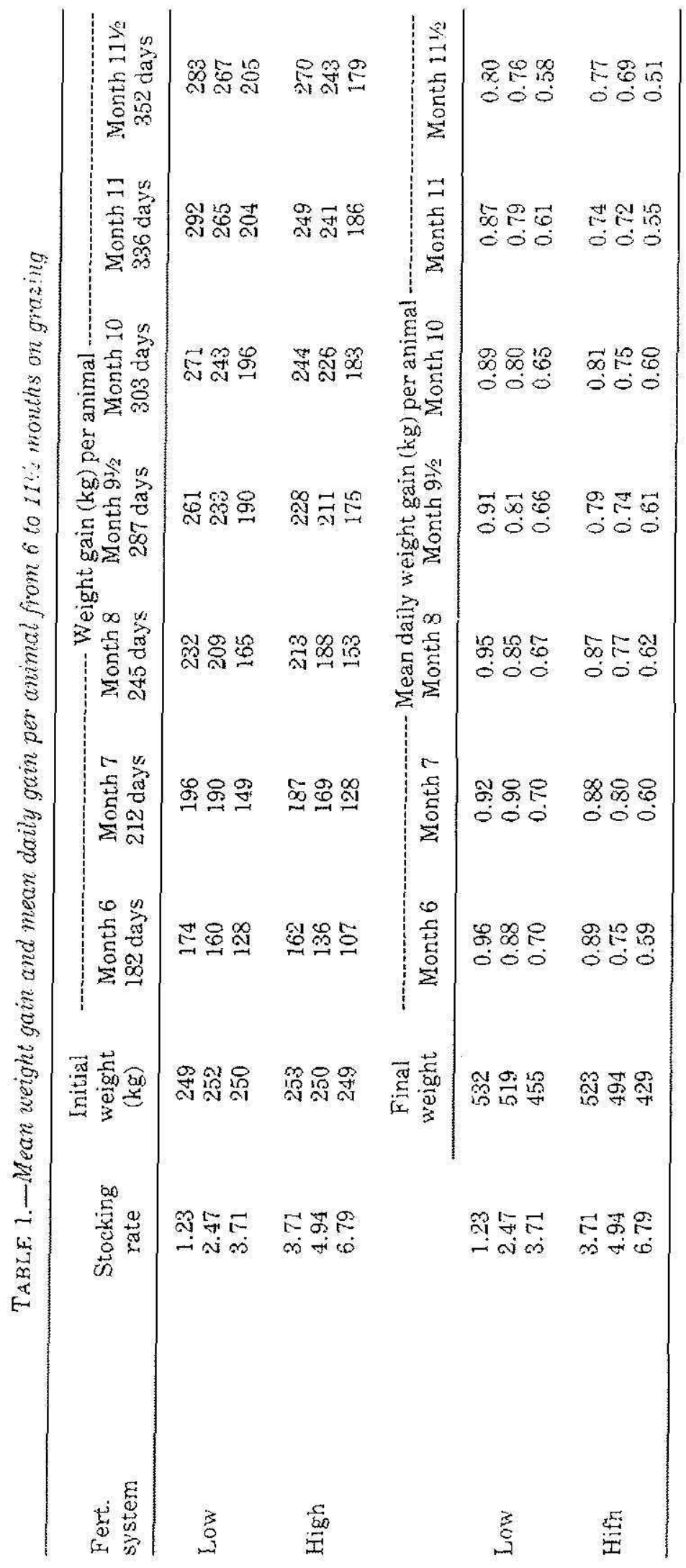


The field trial concluded 15 December 1989 after the animals had grazed the pastures for $11 \frac{1 / 2}{2}$ months.

\section{RESULTS AND DISCUSSION}

Table 1 shows the animal performance data from 6 to $11 \frac{112}{2}$ months on grazing. The final weight of the animals and the mean daily weight were higher than expected, suggesting that the carrying capacity of the pastures under the prevailing conditions is higher than the carrying capacity determined in other studies $(3,5)$.

The mean daily gain for the low and medium stocking rate treatments for both systems after 8 months on grazing ranged from 0.77 to $0.95 \mathrm{~kg}$ per animal, which is considered very good for grazing animals. Figure 1 shows the mean daily weight gain from the beginning of the field trial. In general the mean daily weight gain declined from the beginning of the field trial on. T-5 and T-6 differed from the other treatments since their mean daily gain increased for 3 and 6 months, respectively, after a sharp drop during the second month on grazing. The sharp decline at the earlier stage could be due to the fact that pasture production and availability is normally lower during the winter season. Since these treatments were the ones with highest stocking rates, they probably felt more sharply this seasonal effect. This initial shortage was probably increased by the first month stocking rate, which was set initially higher for $\mathrm{T}-5$ and T-6 and adjusted at the end of the first month. What followed could be explained as a compensatory growth of the animals because of the increasing availability of pastures with the approaching of the longer summer days.

Figure 2 shows the mean animal weight of the various treatments through the duration of the field trial and the regression coefficient of 2nd degree growth curves that were fitted to the data. Each point in the curve represents the mean weight of the treatment animals at that time. The regression equation fitted very well to the data and shows a moderate decline in growth rate for the low and intermediate stocking rate treatments as the experiment progressed. The decline was steeper for T-3. Only in T-6 was the curve unable to cut through the observed points and tended to slightly overestimate the mean weight during the first growth stages and subestimate it at the later stages, with the exception of the last month. This behavior seems to have been caused by the initial decline of growth rate of T-6 as discussed earlier.

A straight line equation was fitted to the data at various stages of the study to describe the relationship between weight gain per animal and stocking rate. It was used to estimate the stocking rate for maximum beef production at those stages, and to predict the expected gain per animal, and gain per hectare (table 2). Since it is assumed that the rela- 
J. Agric. Univ. P.R. vol. 76, No. 3-4, JULY/OCtober, 1992137

Low Fertilization System Treatments
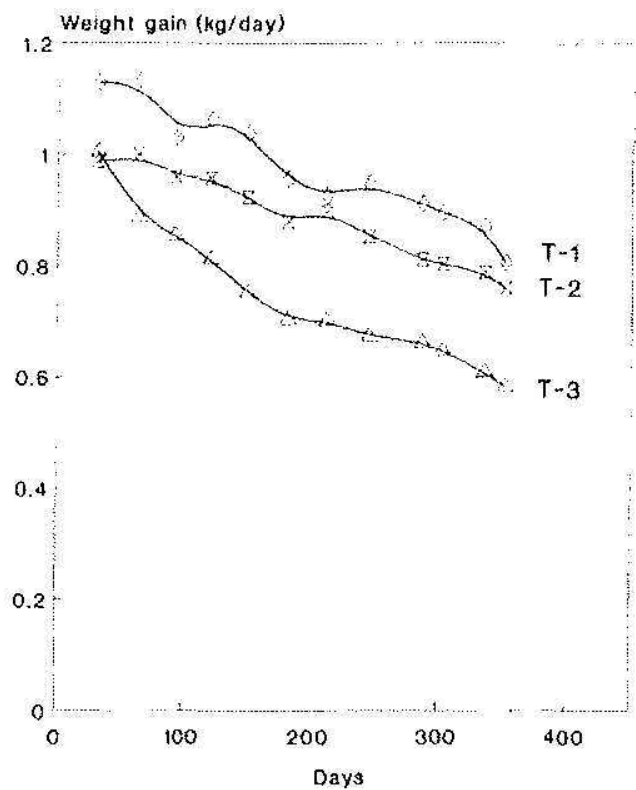

High Ferlilization System Treatments

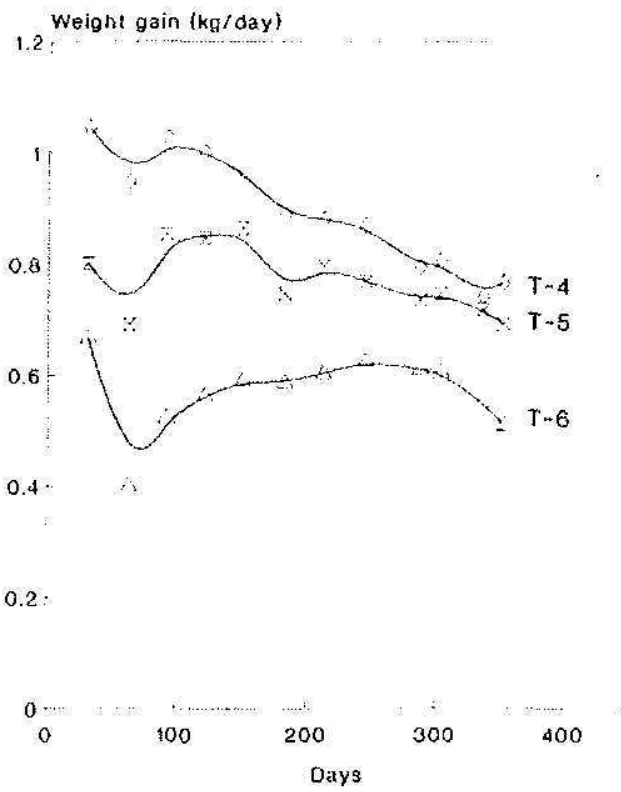

FIG. 1-Mean daily weight gains from the beginning of the grazing trial,

Low Fertilization Systent Treatments

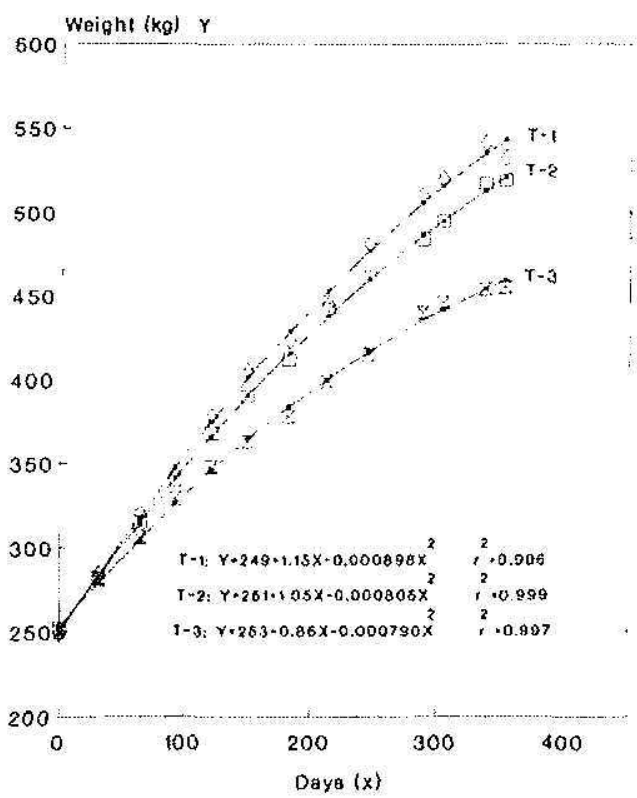

High Fertitization System Treatinents

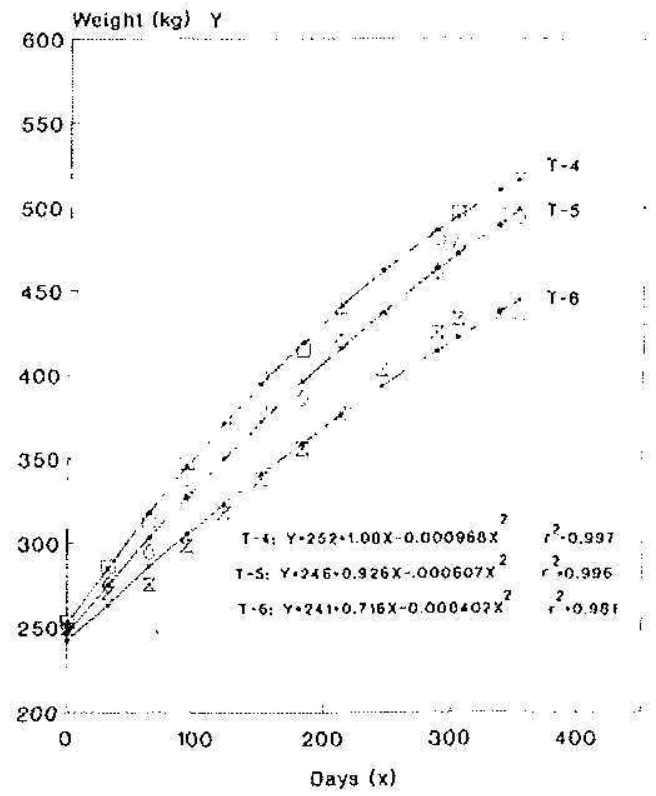

FIG. 2 - Scatter diagrams and estimated growth curves. 
tion between gain per animal and stocking rate is represented by the straight line equation, it follows that meat production per hectare will be the product of the gain per animal equation and stocking rate. The resulting equation is a quadratic of the form: $y=A x+B x^{2}$, where $x$ represents the stocking rate and $y$ the meat production per hectare. The stocking rate for maximum meat production is hence obtained by finding the stocking rate that makes equal to 0 the first derivative of the equation with respect to stocking rate.

Table 2 shows the stocking rates that result in maximum weight gain per hectare for each fertilization system after the animals had grazed the pastures from 6 to $11 \frac{1}{2}$ months. The stocking rate for maximum net returns lies under these stocking rates since adding more animals beyond this point will result in lowering meat production per unit area. The higher stocking rate treatment chosen for both fertilization systems was always very close to or smaller than the stocking rate for maximum beef production per hectare which is adequate for the study, since we wanted to keep the treatment points not too far from the economic range. The lower stocking rates for both treatments were always within the linearity range as established by Jones and Sandland (7).

TABLE 2.-Linear regresion equation for weight gain per head, correlation coefficient, stocking rate for maximum production, and estimated maximum meat production per hectare for the high and low fertitization systems after grazing from 6 to $111 / 2$ months

\begin{tabular}{|c|c|c|c|c|}
\hline Month - days & Regression equation' & $\mathrm{r}$ & $\begin{array}{l}\text { Stocking rate } \\
\text { for max. prod. } \\
\text { Animals } / \text { ha }\end{array}$ & $\begin{array}{l}\text { Gain kg/ha } \\
\text { at max. prod }\end{array}$ \\
\hline & \multicolumn{4}{|c|}{ Low Fertilizer System - } \\
\hline $06 / 182 d$ & $Y=199.3-18.41 X$ & 0.975 & 5.41 & 539 \\
\hline $07 / 212 \mathrm{~d}$ & $Y=225.7-19.14 X$ & 0.917 & 5.89 & 665 \\
\hline $08 / 245 \mathrm{~d}$ & $Y=268.7-26.98 X$ & 0.984 & 4.98 & 669 \\
\hline $91 / 2 / 287 d$ & $Y=299.2-28.84 X$ & 0.994 & 5.19 & 776 \\
\hline $10 / 303 \mathrm{~d}$ & $Y=311.5-30.24 X$ & 0.989 & 5.15 & 802 \\
\hline $11 / 336 \mathrm{~d}$ & $Y=341.5-35.48 X$ & 0.977 & 4.81 & 822 \\
\hline $111 / 2 / 352 d$ & $Y=329.8-31.65 X$ & 0.947 & 5.21 & 859 \\
\hline $06 / 182 \mathrm{~d}$ & $Y=225.6-17.64 X$ & 0.997 & 6.39 & 721 \\
\hline $07 / 212 d$ & $Y=260.6-19.34 X$ & 0.994 & 6.74 & 878 \\
\hline $08 / 245 d$ & $Y=284.1-19.31 X$ & 0.999 & 7.36 & 1,045 \\
\hline $91 / 287 d$ & $Y=293.5-17.25 X$ & 0.996 & 8.51 & 1,249 \\
\hline $10 / 303 \mathrm{~d}$ & $Y=320.4-19.93 X$ & 0.993 & 8.04 & 1,287 \\
\hline $11 / 336 \mathrm{~d}$ & $Y=335.0-21.35 X$ & 0.957 & 7.85 & 1,315 \\
\hline $111 / 2 / 352 \mathrm{~d}$ & $Y=383.8-29.71 X$ & 0.993 & 6.46 & 1,239 \\
\hline
\end{tabular}

1-Y represents the weight gain per head and $x$ the stocking rate. Three points were used to develop the equations, where each one corresponds to the mean weight gain of the stocking rate treatment. 
A visual evaluation of the botanical composition of the pastures was carried out to assess the relative persistence of the stargrass in the various treatments. Figure 3 shows the percentage of stargrass stand from the beginning of the study through close to 1 year after its conclusion. The Stargrass content did not substantially change during the study with the exception of that of T-1, which decreased from 87\% in January 1989 to $67 \%$ in November 1989. However, the stargrass content of all treatments had substantially decreased by October 1990, 10 months after the study ended.

The land where the study was performed was previously planted to several grasses which eventually emerged within the stargrass pastures. No effort was made to control their growth since this would have highly increased the operational costs. By October 1990 more than $97 \%$ of the grass stand of all treatments other than T-3 were composed of stargrass or these other grasses. With regard to T-3 pastures, only $69 \%$ of the area was composed of the mixture and $31 \%$ was invaded by undesirable species, particularly by paspalum (Paspalum conjugatum Berg). Although this species is undesirable, no effort was made to control it because of cost. The spreading of paspalum may have been triggered by the high grazing pressure during the last month of the study, when the animals were very heavy and the pasture growth was slow because of the season.

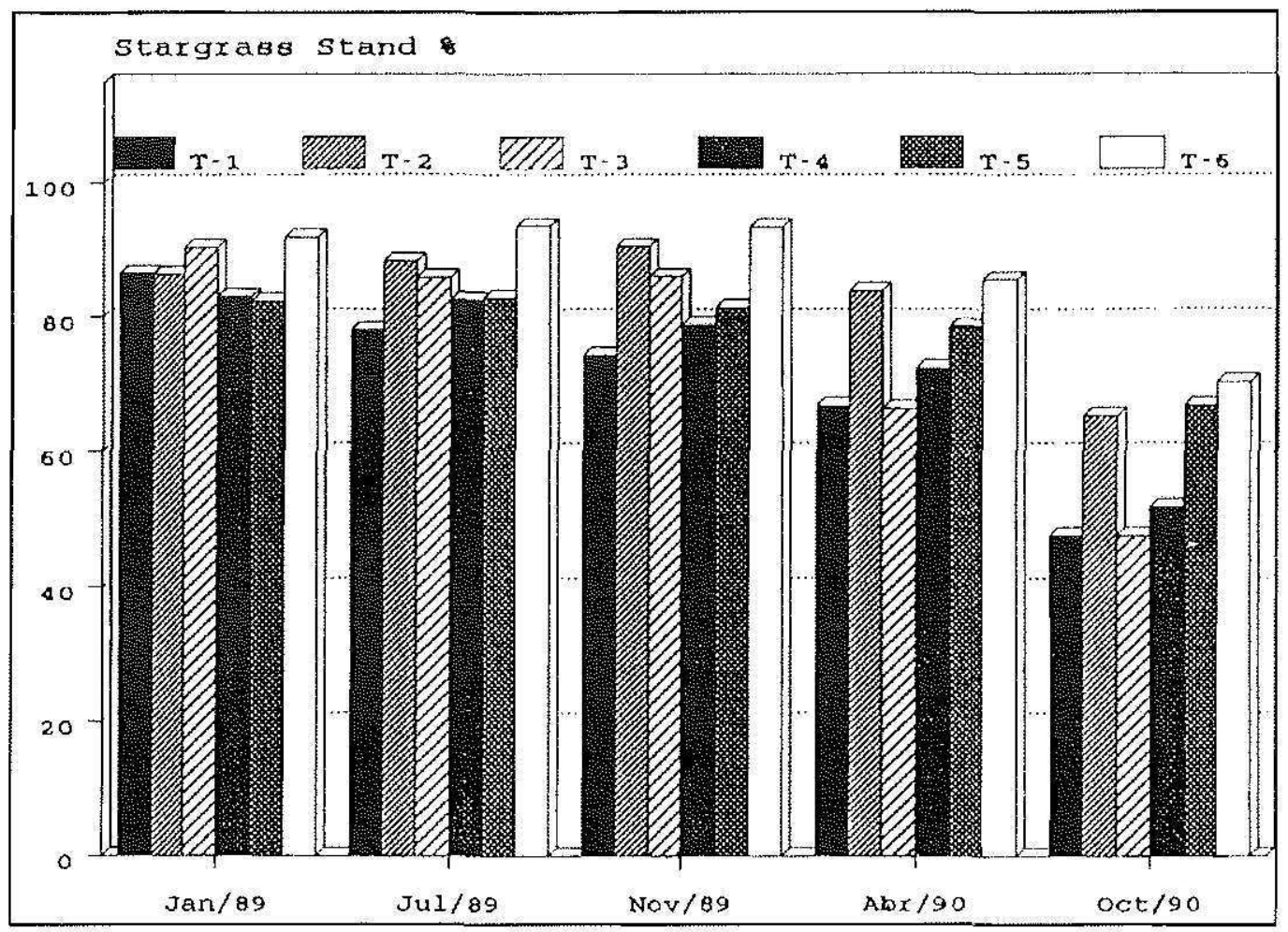

FIG. 3-Percentage of stargrass stand from January 1989 to October 1990. 


\section{Economic evaluation}

The economic evaluation of the production systems presented below should help in the determination of which system and stocking rate provides maximum economic returns under specific price/cost relationships. It should also be valuable in assessing how cost factor changes affect the expected economic returns, stocking rates, and fertilization system performance. What we present here serves only as a general guideline for economic decision making. There are limitations, both in the extent of the data collected-the study was carried on for only one year-as well as in the cost factor utilized for the preparation of the various partial budgets. These budgets do not take into consideration cost factors such as land rent, pasture and fence investment and depreciation, or income for management, among others. Accordingly, the net returns presented here are that portion of the total income that remains after the deduction of the stated cost, for the payment of the other cost factors not considered, and for profit. It should be pointed out, however, that the net returns are given per hectare, and those cost factors not included but similar among the production systems, such as the cost of land, should not affect the relative performance of the systems. Table 3 shows the amount of labor and materials required for the execution of the activities carried out in the field trial.

Since the time factor is another variable influencing the performance of the meat production system under study, a series of budgets were developed to show how the economic "optimum" stocking rates and expected net returns of each system vary with increasing grazing time. This approach will help the cattlemen choose not only the most convenient production system, but also the most favorable time for selling the animals. The introduction of the time factor makes difficult the handling of the data for the estimation of the various stocking rates; therefore, some assumptions had to be made to prorate the use of some cost factors through the different time frames. The fertilizer expenses, for example, although applied in 2 to 4 portions yearly, were expressed on a cost per day basis and charged to the various evaluation periods according to the grazing days included.

The net return per hectare of land (NR) is given by the difference between the gross receipt from the sales of bulls (GR) and the total cost (TC) (9).

$$
N R=G R-T C
$$

The gross return portion of the profit equation is determined by the selling price of the cattle (Ps), the stocking rate (S), and the final weight

of the animals. Since the final weight can be estimated by the adding of the initial weight $(\mathrm{W})$ to the gain in weight obtained during the grazing 
TABIE 3.-Labor and malerials required for the activities performed in the field trial adjusted to per-year basis

\begin{tabular}{|c|c|c|}
\hline Activity & man-hours & Amount; \\
\hline Fertilization; labor (T1-T3)/ha/year', 2 applications & $11.5 \mathrm{I}$ & 38.05 \\
\hline Fertilization; labor(T4-T6)/ha/year, 4 applications & 34.50 & 113.73 \\
\hline Weed control; labor/ha/year & 5.03 & 16.63 \\
\hline Weed control; Roundup 1L/ha/year & & 22.19 \\
\hline Mineral consumption; $12.5 \mathrm{Kg} /$ animal.year & & 5.25 \\
\hline Health care; labor/animal/year & 0.7184 & 2.38 \\
\hline Tick control treatments; Labor/animal & 0.3256 & 1.08 \\
\hline Vaccinations"; labor/animal & 0.5834 & 1.93 \\
\hline Vaccine costs; \$/animal & & 1.76 \\
\hline Medicine custs; /animal/year & & 3.22 \\
\hline \multicolumn{3}{|l|}{ Rotation; labor/ha/year for: ${ }^{2}$} \\
\hline$T-1 ;(11.90$ days/rotation) & 1.053 & 3.48 \\
\hline $\mathrm{T}-2 ;(6.86$ days/rotation) & 3.651 & 12.07 \\
\hline $\mathrm{T}-3 ;$ ( 3.63 days/rotation) & 10.855 & 34,23 \\
\hline T-4; (6.03 days/rotation) & 6.228 & 20.59 \\
\hline T'-5; (3.72 days/rotation) & 10.093 & 33.37 \\
\hline T-6; (3.45 days/rotation) & 10.889 & 36.00 \\
\hline
\end{tabular}

1-Manual fertilization

2-Estimated assuming rotatians among adjacent pastures and 0.167 man-hours per rotation.

3-Two vaccines (vermicidal) per animal.

4-Two insecticide applications/animal; insecticide provided free under government program.

5 -All costs calculated assuming a wage rate of $\$ 2.85 / \mathrm{hr}$ and $16 \%$ fringe benefits.

period-as estimated by the corresponding production function-it follows that the gross return per hectare for the various weighing periods of the study is given by the following equation: $G R=\operatorname{Ps}(W+A-B \times S) S$, where $A$ and $B$ are the regression coefficients of the corresponding meatstocking rate production function.

The total cost (TC) part of the profit function is in general determined by two kinds of cost factors. The first is composed by the cost (C1) incurred in the purchase, handling, and care of the animals, as well as the interest charges to finance these activities. This kind of cost is represented here on per animal basis. The other kind of cost factors (C2) are those incurred for the land and pasture cost, and their corresponding interest charge, and is being represented here on per hectare basis. Total cots per hectare can then be represented as follows: $\mathrm{TC}=\left(\mathrm{P}_{\mathrm{p}} \times \mathrm{W}+\mathrm{C} 1\right)\left(\mathrm{S}+\mathrm{C} 2\right.$, where $\mathrm{P}_{\mathrm{p}}$ is the purchase price of the animals.

The cost factors included in the C1 terms were as follows:

1- $\mathrm{M}_{\mathrm{a}}=$ Cost of the materials used per animal during the grazing period. Includes medicines and minerals, which were prorated through time, and two vaccines per animal. 
2- $\mathrm{I}_{\mathrm{a}}=\mathrm{Labor}$ used per animal for two insecticide applications for tick control, for vaccinations and for health treatment. Included is an estimated veterinarian charge of $\$ 136$ for one visit per year prorated among 100 animals. The labor used per animal also includes an estimate of the time expended in the rotation of animals among adjacent pastures, and the cleaning of the watering facilities. Since both activities increase with higher stocking rates, a straight line equation was fitted between the estimated labor cost of adjacent stocking rate treatments to predict the labor cost per hectare needed for the rotation of the animals. The cost for cleaning and watering facilities was estimated to be half of the labor cost incurred in the rotation of animals. The following equation was included in the $L_{\text {. }}$ term to predict labor cost per hectare for the latter activities:

$L_{c}=1.5\left(A_{r}+B_{r} \times S\right)$; where $A_{r}$ and $B_{r}$ are the regression coefficients of the equation.

3- Interest cost per animal to finance the purchase of the animals and per animal related costs.

The cost factors included in the $\mathrm{C} 2$ term were as follows:

1- $M_{h}=$ Materials used per hectare for pasture maintenance. The only costs charged under this category are those for fertilizer and herbicide. The herbicide cost was pooled and expressed on a per hectare basis, thus assuming no difference among treatments of fertilization systems in weed control.

2- $\quad \mathrm{L}_{\mathrm{h}}=$ Labor used per hectare. Includes labor utilized for fertilization and herbicide applications. Does not include labor costs needed for fence maintenance.

3- $\mathrm{I}=$ Interest cost.

Substituting all income and cost factors into equation 1 produces the following equation to represent net returns per hectare above the selected cost items:

$$
\begin{gathered}
N R=P_{s}(W+A-B \times S) S-\left(P_{p} \times W+M_{a}+L_{k}\right)(1+I) S-1.5\left(A_{r}+B_{r} \times S\right)(1+1) \\
-\left(M_{h}+L_{h}\right)(1+I)-P_{p} \times W \times M_{o} \times S
\end{gathered}
$$

All terms in equation 2 were previously defined except the last one, which was included to represent the mortality cost. None of the experiment animals actually died during the study but this factor should be included to discount it from the profit as a risk factor that increases with the stocking rate. $M_{0}$ is the mortality rate, and $I$ the interest rate. 
As customary, the profit equation was differentiated with respect to the stocking rate to find the stocking rate yielding the maximum profit per hectare at the different weighing periods. The resulting equation is as follows.

$$
S=\frac{P_{s}(W+A)-\left(P_{p} W+M_{2}+L_{a}+1.5 B_{r}\right)(1+I)-P_{p} \times W \times M_{o}}{2 P_{s} B}
$$

All terms related to the cost factors included in C2 disappear from the equation, thus making the determination of the various economic optimum stocking rate independent of the costs included in this cost factor. Nevertheless, these terms are important for the comparison of the production systems and are included in the series of tables that were developed to analyze the performance of the production system as different price levels and time frames.

Tables $4 \mathrm{a}$ and $4 \mathrm{~g}$ present the stocking rates for maximum economic returns as calculated from equation 3 after the animals grazed the pastures from 8 to $11 \frac{112}{2}$ months. Each of them shows, side by side, the performance of both production systems under specific price factor showing the net income to be expected from the systems over the cost factors included. Prices such as animal purchase and selling prices, fertilizer price, interest rate, and labor cost were changed to evaluate the effect of the changes over each system and their relative importance.

Table 4a shows the performance of the systems with price levels similar to the local prices present by the time the experiment ended. The actual selling price of the animals varied from $\$ 1.41 / \mathrm{kg}$ liveweight obtained for the heavier animals to $\$ 1.34$. The purchasing price for feeder cattle was up to $\$ 1.55 / \mathrm{kg}$; the fertilizer price, $\$ 203.90 / \mathrm{t}$; and the wage rate and fringe benefits, $\$ 2.85 / \mathrm{h}$ and $16 \%$, respectively. No government rebates were included in the budgets. The interest rate was set at 10\%; it was varied in other budgets to measure its effect on the system. The mortality rate was set at $1.5 \%$.

Under the prices included in table $4 a$, it seems that the best economic returns could be achieved by selecting the low fertilization system (System A) and a stocking rate close to 3.8 animals per hectare after grazing: the animals for about 10 months, since the additional income after this period is very small. The best approach should be that of initially selling the heavier animals since the lowering of the grazing pressure at this stage will benefit the remaining animals, thus probably increasing their weight gain for the remaining growth period. The decreasing of the grazing pressure will also benefit the pastures since during the later period, particularly the last month, the grazing pressure was too high. 
TABLE 4,a-SStocking rale for maximum economic returns over selected cost items for the high and low fertilization lovel systems from 8 to 111/: grazing months. Price levels similar to local prices by the time the experiment ended

\begin{tabular}{|c|c|c|c|c|c|}
\hline & $\begin{array}{l}\text { Month } 8 \\
245 \text { days }\end{array}$ & $\begin{array}{r}\text { Month } 91 / 2 \\
287 \text { days }\end{array}$ & $\begin{array}{r}\text { Month } 10 \\
303 \text { days }\end{array}$ & $\begin{array}{l}\text { Month } 11 \\
336 \text { days }\end{array}$ & $\begin{array}{l}\text { Month } 111 / 2 \\
352 \text { days }\end{array}$ \\
\hline \multicolumn{6}{|l|}{ Loufent system } \\
\hline Stocking rate (head/ha) & 3.66 & 3.83 & 3.81 & 3.59 & 3.80 \\
\hline \multirow{2}{*}{$\begin{array}{l}\text { Expected income } \\
\text { Cost of animals }\end{array}$} & 2169.22 & 2373.46 & 2402.40 & 2355.02 & 2467.58 \\
\hline & 1421.31 & 1488.87 & 1481.84 & 1397.06 & 1478.16 \\
\hline Material cost & 164.84 & 193.47 & 203.72 & 223.08 & 235.48 \\
\hline Labor cost & 91.49 & 110.05 & 115.03 & 119.41 & 131.46 \\
\hline Interest cost & 91.49 & 140.94 & 149.47 & 160.13 & 177.94 \\
\hline Mortality & 21.32 & 22.33 & 22.23 & 20.96 & 22.17 \\
\hline Net income & $\$ 357.65$ & $\$ 417.81$ & $\$ 430.12$ & $\$ 434.88$ & $\$ 422.32$ \\
\hline \multicolumn{6}{|l|}{ High fert system } \\
\hline Stocking rate (head/ha) & 5.85 & 6.69 & 6.42 & 6.25 & 5.28 \\
\hline Expected income & 3480.00 & 4045.31 & 4011.09 & 3988.99 & 3558.41 \\
\hline Cost of aninals & 2273.81 & 2600.49 & 2495.21 & 2431.45 & 2054.31 \\
\hline Material cost & 472.71 & 559.08 & 587.20 & 648.35 & 669.04 \\
\hline \multirow{2}{*}{$\begin{array}{l}\text { Labor cost } \\
\text { Interest cost }\end{array}$} & 155.67 & 185.33 & 192.55 & 210.14 & 211.44 \\
\hline & 194.80 & 263.01 & 271.87 & 302.85 & 283.03 \\
\hline Mortality & 34.11 & 39.01 & 37,43 & 36.47 & 30.81 \\
\hline Net income & $\$ 348.90$ & $\$ 398.40$ & $\$ 426.84$ & $\$ 359.72$ & $\$ 309.79$ \\
\hline$p$ & & & & & \\
\hline price $/ \mathrm{kg}$ & Int & rest rate & $=10.0 \%$ & nual & \\
\hline Initial weight $(\mathrm{kg})$ & Wage & e rate $/ \mathrm{hr}^{2}$ & $-\$ 2.85 h$ & & \\
\hline Mortality rate & Fring & e benefits & $\approx 16.0 \%$ & & \\
\hline
\end{tabular}

In table $4 \mathrm{~b}$ the selling price of the animals was set at $\$ 1.34 / \mathrm{kg}$, which was the mean price registered in the San Sabastián local rural market for the year $1988-89$, and the purchasing price was set at $\$ 1.48 / \mathrm{kg}$ or $10.4 \%$ higher. This represents a $\$ 0.14 / \mathrm{kg}$ price spread between purchasing and selling prices, which is typical in the local market. Under this scenario the selected stocking rate and selling approach is similar to that of table $4 a$, except that the expected returns are lower. The price spread in table $4 \mathrm{a}$ is also $\$ 0.14 / \mathrm{kg}$. It is worth notice that the higher meat price (5.2\% higher) in this table are compared to the other cost factors increased the relative performance of the high fertilization system but the meat price was not high enough to make this system outperform system B. Table $4 \mathrm{~b}$ will serve as a base (standard) to measure the influence that changes in selected cost factors have on the system's performance. When the economic stocking rates determined here are compared to the corresponding stocking rates to achieve maximum meat production per hectare in table 2, the economic optimum under the present price levels lies between $72 \%$ and $74 \%$ of the stocking rate required to achieve maximum production for the low fertilization system, and $78 \%$ to $81 \%$ of the corresponding stocking rates for the high fertilization system. 
TARIF 4.b-Selling price of the animals set to the mean price registered at the San Sabastian tocal mural market for the year 1988-89.

\begin{tabular}{|c|c|c|c|c|c|}
\hline & $\begin{array}{l}\text { Month } 8 \\
245 \text { days }\end{array}$ & $\begin{array}{r}\text { Month } 91 / 2 \\
287 \text { days }\end{array}$ & $\begin{array}{l}\text { Month } 10 \\
303 \text { days }\end{array}$ & $\begin{array}{l}\text { Month } 11 \\
336 \text { days }\end{array}$ & $\begin{array}{r}\text { Month } 111 / 2 \\
352 \text { days }\end{array}$ \\
\hline \multicolumn{6}{|l|}{ Lom fer! syslem } \\
\hline Stocking rate (head/ha) & 3.61 & 3.78 & 3.76 & 3.55 & 3.75 \\
\hline Expected income & 2039.29 & 2232,65 & 2260.39 & 2217.21 & 2320.88 \\
\hline Cost of animals & 1338.32 & 1402.63 & 1396.28 & 1317.15 & 1392.08 \\
\hline Material cost & 164.47 & 193.04 & 203.28 & 222.66 & 234.98 \\
\hline Labor cost & 90.30 & 108.68 & 113.61 & 118.01 & 129.79 \\
\hline Interest cost & 106.93 & $134.0 \mathrm{I}$ & 142.22 & 152.61 & 169.43 \\
\hline Mortality & 20.07 & 21.04 & 20.94 & 19.76 & 20.88 \\
\hline Net income & $\$ 319.19$ & $\$ 373.24$ & $\$ 384.06$ & $\$ 387.02$ & $\$ 373.73$ \\
\hline \multicolumn{6}{|l|}{ High fert system } \\
\hline Stocking rate (head/ha) & 5.80 & 6.63 & 6.37 & 6.20 & 5.25 \\
\hline Expected income & 3284.68 & 3817.79 & 3788.22 & 3767.78 & 3364.54 \\
\hline Cost of animals & 2151.40 & 2460.04 & 2362.24 & 2302.08 & 1947.18 \\
\hline Material cost & 472.33 & 558.57 & 586.74 & 647.86 & 668.67 \\
\hline Labor cost & 155.34 & 184.90 & 192.16 & 209.74 & 211.14 \\
\hline Interest cost & 186.54 & 251.89 & 260.76 & 290.86 & 272.63 \\
\hline Mortality & 32.27 & 36.90 & 35.43 & 34.53 & 29.21 \\
\hline Net income & $\$ 286.81$ & $\$ 325.49$ & $\$ 350.89$ & $\$ 282.70$ & $\$ 235.71$ \\
\hline
\end{tabular}

Selling price/kg $=\$ 1.34$

Buying price/kg $=\$ 1.48$

Hildreth and Riewe (6), analyzing the effect of the economic variables on stocking rate, found that a major factor in determining the economic stocking rate is the buying and selling price of the animals. Tables $4 \mathrm{c}$ and $4 \mathrm{~d}$ were developed to measure that effect on our particular circumstances. In table $4 \mathrm{c}$ the purchasing price of the animals was lowered to $\$ 1.41 / \mathrm{kg}$, thus lowering the price spread to $\$ 0.07 / \mathrm{kg}$, which is half of that of table $4 \mathrm{~b}$. Under this scenario the best economic returns could now be achieved by selecting the high fertilization system (System B), and a stocking rate of 6.7 animals per hectare. The estimated return from the partial costs increased from. $\$ 384 /$ ha expected in table $4 \mathrm{~b}$ to $\$ 477$. When the price margin is 0 (table $4 \mathrm{~d}$ ), the expected income increases to $\$ 612 / \mathrm{ha}$.

Table 4e was made to assess the effect of the interest rate on the systems. It shows that a drop of $20 \%$ in the rate-from $10 \%$ to $8 \%$-increases the expected income for System A after 10 grazing months from $\$ 384$ in table $4 b$ to $\$ 413$, for a $7 \%$ increase. The expected income for System B increased from $\$ 351$ to $\$ 403$ for a $\$ 5 \%$ increase. Under this scenario System A remains the best alternative although the difference between them is now lower. Both "economic" stocking rates increased.

Table $4 \mathrm{f}$ shows the effect of a $20 \%$ increase in fertilizer price as compared to table $4 \mathrm{~b}$. This change lowered the expected income for System A after 10 months by $\$ 33 /$ ha or $9 \%$, and that of System B by $\$ 111$ or $32 \%$. 
TABLE 4.c-Purchasing mice of the animals set lo lower the buyng-selling price spread to $\$ 0.07 / \mathrm{kg}$

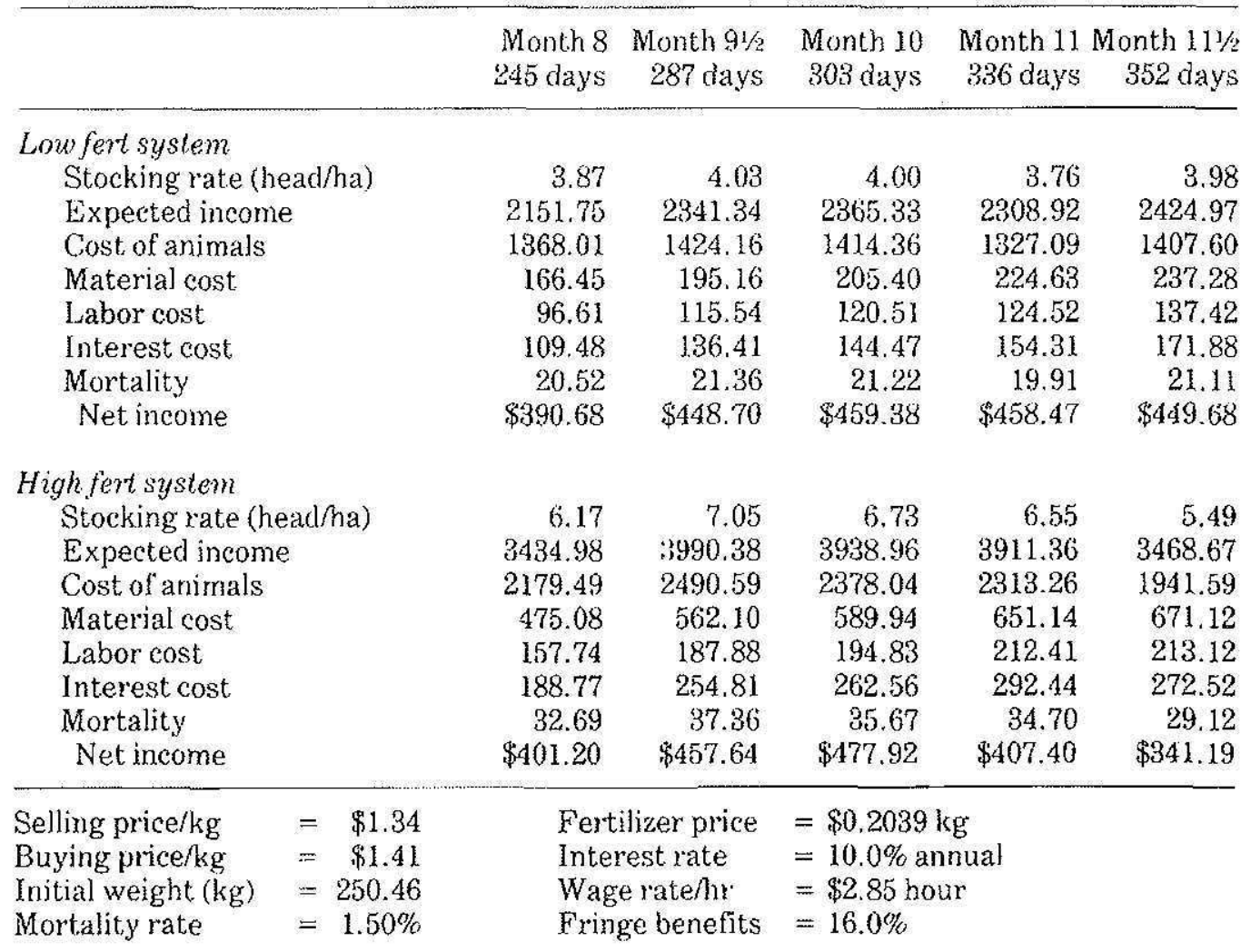

TABLE 4.d-Purchasing price of the anmals set equal to the selling price to cancel the price spread

\begin{tabular}{lrrrrr}
\hline & Month 8 & Month 91/2 & Month 10 & \multicolumn{2}{r}{ Month 11 Month 111/2 } \\
& 245 days & 287 days & 303 dlays & 336 days & 352 days \\
\hline Low fert system & & & & & \\
Stocking rate (headha) & 4.14 & 4.28 & 4.24 & 3.96 & 4.21 \\
Expected income & 2259.16 & 2445.20 & 2465.63 & 2396.61 & 2524.52 \\
Cost of animals & 1388.36 & 1436.87 & 1424.00 & 1329.77 & 1414.93 \\
Material cost & 168.42 & 197.27 & 207.51 & 226.60 & 239.59 \\
Labor cost & 102.92 & 122.40 & 127.40 & 131.02 & 145.05 \\
Interest cost & 111.40 & 138.12 & 146.01 & 155.33 & 173.55 \\
Mortality & 20.83 & 21.55 & 21.36 & 19.95 & 21.22 \\
Net income & $\$ 467.22$ & $\$ 528.99$ & $\$ 539.36$ & $\$ 533.94$ & $\$ 530.17$ \\
& & & & & \\
High fert system & & & & & \\
Stocking rate (head/ha) & 6.54 & 7.47 & 7.09 & 6.89 & 5.74 \\
Expected income & 3578.22 & 4154.88 & 4082.67 & 4048.25 & 3567.95 \\
Cost of animals & 2194.52 & 2506.37 & 2381.02 & 2312.36 & 1927.28 \\
Material cost & 477.84 & 565.63 & 593.14 & 654.42 & 673.58 \\
Labor cost & 160.15 & 190.85 & 197.50 & 215.09 & 215.11 \\
Interest cost & 190.13 & 256.56 & 263.29 & 292.91 & 271.57 \\
Mortality & 32.92 & 36.60 & 35.72 & 34.69 & 28.51 \\
$\quad$ Net income & $\$ 522.66$ & $\$ 597.87$ & $\$ 612.00$ & $\$ 538.79$ & $\$ 451.51$ \\
\hline
\end{tabular}

Selling price $/ \mathrm{kg}=\$ 1.34$

Buying price/kg $=\$ 1.34$ 
J. Agric. Uniw. P.R. voL. 76, NO. 3-4, JULY/OCTOBER, 1992147

TABLE 4.e-Interest rate lowered by $20 \%$ to assess its effect on the systems

\begin{tabular}{|c|c|c|c|c|c|c|}
\hline & $\begin{array}{l}\text { Month } 8 \\
245 \text { days }\end{array}$ & $\begin{array}{r}\text { Month } 9^{1 / 2} \\
287 \text { days }\end{array}$ & $\begin{array}{l}\text { Month } 10 \\
303 \text { clays }\end{array}$ & $\begin{array}{l}\text { Month } 11 \\
336 \text { days }\end{array}$ & $\begin{array}{l}\text { Month } 111 / 2 \\
352 \text { dajs }\end{array}$ \\
\hline \multicolumn{7}{|l|}{ Low fert system } \\
\hline \multicolumn{2}{|c|}{ Stocking rate (head/ha) } & 3.68 & 3.86 & 3.85 & 3.63 & 3.85 \\
\hline \multirow{2}{*}{\multicolumn{2}{|c|}{$\begin{array}{l}\text { Expected income } \\
\text { Cost of animals }\end{array}$}} & 2071.58 & 2269.18 & 2297.62 & 2253.27 & 2363.75 \\
\hline & & 1366.03 & 1433.34 & 1427.33 & 1346.76 & 1427.01 \\
\hline \multicolumn{2}{|l|}{ Material cost } & 165.03 & 193.74 & 204.03 & 223.42 & 235.91 \\
\hline \multicolumn{2}{|l|}{ Labor cost } & 92.09 & 110.95 & 116.03 & 120.54 & 132.89 \\
\hline \multicolumn{2}{|l|}{ Interest cost } & 87.16 & 109.33 & 116.05 & 124.51 & 138.55 \\
\hline \multicolumn{2}{|l|}{ Mortality } & 20.49 & 21.50 & 21.41 & 20.20 & 21.41 \\
\hline \multicolumn{2}{|l|}{ Net income } & $\$ 340.77$ & $\$ 400.31$ & $\$ 412.78$ & $\$ 417.84$ & $\$ 407.99$ \\
\hline \multicolumn{7}{|l|}{ High fert system } \\
\hline \multicolumn{2}{|c|}{ Stocking rate (head/ha) } & 5.90 & 6.76 & 6.49 & 6.33 & 5.34 \\
\hline \multirow{2}{*}{\multicolumn{2}{|c|}{$\begin{array}{l}\text { Expected income } \\
\text { Cost of animals }\end{array}$}} & 3326.01 & 4872.96 & 3838.95 & 3821.05 & 3404.90 \\
\hline & & 2188.45 & 2508.83 & 2406.88 & 2348.46 & 1982.14 \\
\hline \multicolumn{2}{|l|}{ Material cost } & 473.07 & 559.68 & 587.80 & 649.06 & 669.61 \\
\hline \multicolumn{2}{|l|}{ Labor cost } & 155.99 & 185.84 & 193.05 & 210.72 & 211.90 \\
\hline \multicolumn{2}{|l|}{ Interest cost } & 151,30 & 204.71 & 221.70 & 236.27 & 220.93 \\
\hline \multicolumn{2}{|l|}{ Mortality } & 32.83 & 37.68 & 36.10 & 35.23 & 29.73 \\
\hline \multicolumn{2}{|l|}{ Net income } & $\$ 324.38$ & $\$ 376.27$ & $\$ 403.43$ & $\$ 341.32$ & $\$ 290.59$ \\
\hline & $\$ 1.3$ & & & & & \\
\hline & $=\$ 1.48$ & Inte & est rate & $=8.0 \%$ & lual & \\
\hline itial weight ( $\mathrm{kg}$ ) & $=250.46$ & Wag & rate/hr & $=\$ 2.85 \mathrm{ho}$ & & \\
\hline Mortality rate & $=1.50 \%$ & Frin & ge benefits & $=16.0 \%$ & & \\
\hline
\end{tabular}

TABLE 4. -Fertilizer price increased by $20 \%$ to assess its effect on the systems

\begin{tabular}{|c|c|c|c|c|c|}
\hline & $\begin{array}{l}\text { Month } 8 \\
245 \text { days }\end{array}$ & $\begin{array}{r}\text { Month } 91 / 2 \\
287 \text { days }\end{array}$ & $\begin{array}{r}\text { Month } 10 \\
303 \text { days }\end{array}$ & $\begin{array}{l}\text { Month } 11 \\
336 \text { days }\end{array}$ & $\begin{array}{l}\text { onth } 111 / 2 \\
352 \text { days }\end{array}$ \\
\hline \multicolumn{6}{|l|}{ Lowfert system. } \\
\hline Stocking rate (head/ha) & 3.61 & 3.78 & 3.76 & 3.65 & 3.75 \\
\hline Expected income & 2039.29 & 2232.65 & 2260.39 & 2217.21 & 2320.88 \\
\hline Cost of animals & 1338.32 & 1402.63 & 1396.28 & 1317.15 & 1392.08 \\
\hline Material cost & 189.02 & 221.80 & 233.64 & 256.32 & 270.24 \\
\hline Labor cost & 90.30 & 108.68 & 113.61 & 118.01 & 129.79 \\
\hline Interest cost & 108.58 & 136.27 & 144.74 & 155.71 & 172.83 \\
\hline Mortality & 20.07 & 21.04 & 20.94 & 19.76 & 20.88 \\
\hline Net income & $\$ 292.99$ & $\$ 342.23$ & $\$ 351.18$ & $\$ 350.26$ & $\$ 335.06$ \\
\hline \multicolumn{6}{|l|}{ High fert system } \\
\hline Stocking rate (head/ha) & 5.80 & 6.63 & 6.37 & 6.20 & 5.25 \\
\hline Expected income & 3284.68 & 3817.79 & 3788.22 & 3767.78 & 3364.54 \\
\hline Cost of animals & 2151.40 & 2460.04 & 2362.24 & 2302.08 & 1947.18 \\
\hline Material cost & 555.17 & 655.62 & 689.19 & 761.48 & 787.69 \\
\hline Labor cost & 155.34 & 184.90 & 192.16 & 209.74 & 211.14 \\
\hline Interest cost & 192.10 & 259.52 & 269.26 & 301.32 & 284.11 \\
\hline Mortality & 32.27 & 36.90 & 35.43 & 34.53 & 29.21 \\
\hline Net income & $\$ 198.41$ & $\$ 220.81$ & $\$ 239.93$ & $\$ 158.63$ & $\$ 105.21$ \\
\hline
\end{tabular}


TABLE 4.g-Wages rate increased by $20 \%$ to assess its effect on the systems

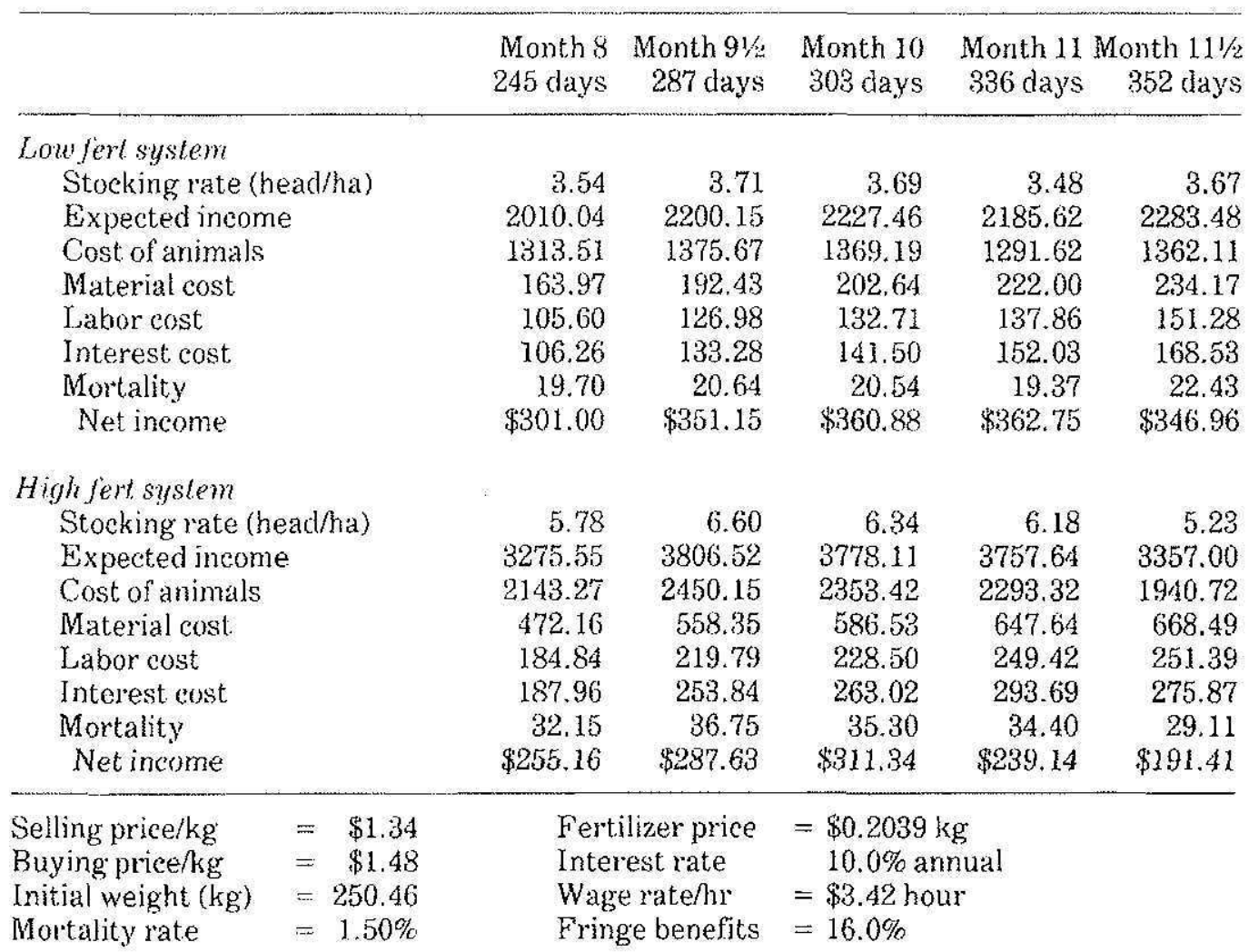

The high fertilization level of System $B$ makes it more sensitive to changes in fertilizer price than System A. The optimum stocking rate did not change in either system since its determination is independent of the fertilizer and fertilization costs.

Table $4 \mathrm{~g}$ shows the effect of a $20 \%$ increase in the wage rate. This change lowered the expected income from System A after 10 months by $\$ 23 /$ ha or $6 \%$, and that of System B by $\$ 40 /$ ha or $11 \%$. System A remains the best performer under this scenario and its recommended stocking rate after 10 months changes from 3.76 to 3.69 .

Table 5 shows the performance of the systems when there is a discontimuity in the selling price of the animals. In the local market the selling price of the heavier animals is usually higher than that of the lighter ones. This table presents the same price scenario as table $4 \mathrm{~b}$ with the exception that the selling price of the animals weighing less than $454 \mathrm{~kg}$ is lowered by $5 \%$, from $\$ 1.34 / \mathrm{kg}$ to $\$ 1.25 / \mathrm{kg}$. Under these circumstances the stocking rates in table $4 \mathrm{~b}$ should be lowered in most instances in order to raise the weight of the animals to at least $454 \mathrm{~kg}$ since the price differential makes more profitable the raising of heavier animals than raising a higher number of animals weighing less that $454 \mathrm{~kg}$. Under this price scenario the selection of the low fertilization system and a 10 - to 11-month grazing period remains the best choice. 
TABLE 5.--Stocking rate for maximum economic returns over selected cost items for the high and low fertiliation level systems from 8 to $11 \% / 2$ grazing months with a $5 \%$ discount in selling price for animals weighing less than $4,54 \mathrm{~kg}$

\begin{tabular}{|c|c|c|c|c|c|}
\hline & $\begin{array}{l}\text { Month } 8 \\
245 \text { days }\end{array}$ & $\begin{array}{r}\text { Month } 91 / 2 \\
287 \text { days }\end{array}$ & $\begin{array}{l}\text { Month } 10 \\
303 \text { days }\end{array}$ & $\begin{array}{l}\text { Month } 11 \\
336 \text { days }\end{array}$ & $\begin{array}{r}\text { Month } 111 / 2 \\
352 \text { days }\end{array}$ \\
\hline \multicolumn{6}{|l|}{ Low fert system } \\
\hline Stocking rate (head/ha) & 2.41 & 3.32 & 3.57 & $3 ., 35$ & 3.75 \\
\hline Estimated mean weight & 404 & 454 & 454 & 466 & 462 \\
\hline Expected income & 1468.97 & 2018.40 & 2172.06 & 2217.21 & 2320.88 \\
\hline Cost of animals & 895.69 & 1230.71 & 1324.40 & 1317.15 & 1392.08 \\
\hline Material cost & $15 \overline{5}, \overline{3} 6$ & 189.13 & 201.58 & 222.66 & 234.98 \\
\hline Labor cost & 61.83 & 95.97 & 108,03 & 118.01 & 129.79 \\
\hline Interest cost & 74.71 & 119.19 & 135.65 & 152.61 & 169.43 \\
\hline Mortality & 13.44 & 18.46 & 19.87 & 19.76 & 20.88 \\
\hline vet income & $\$ 267.73$ & $\$ 364.9 \overrightarrow{0}$ & $\$ 382.54$ & $\$ 387.02$ & $\$ 373.73$ \\
\hline \multicolumn{6}{|l|}{ High fert system } \\
\hline Stocking rate (head/ha) & 4.1742 & 5.22 & 5.86 & 6.16 & 5.25 \\
\hline Estimated mean weight & 454 & 454 & 454 & 454 & 478 \\
\hline Expected income & 2540.19 & 3173.94 & 3566.77 & 3749.08 & 3364.54 \\
\hline Cost of animals & 1548.87 & 1935.30 & 2174.82 & 2285.98 & 1947.18 \\
\hline Material cost & 460.20 & 546.63 & 582.28 & 647.45 & 668.67 \\
\hline Labor cost & 144.75 & 174.83 & 188.45 & 209.40 & 211.14 \\
\hline Interest cost & 144.56 & 208.90 & 244.52 & 289.31 & 272.63 \\
\hline Mortality & 23.23 & 29.03 & 33.62 & 34.29 & 29.21 \\
\hline Net income & $\$ 218.56$ & $\$ 279.26$ & $\$ 344.07$ & $\$ 282.65$ & $\$ 235.71$ \\
\hline$=\$ 1.341$ & \multicolumn{2}{|c|}{ Fertilizer price } & \multicolumn{3}{|c|}{$=\$ 0.2039 \mathrm{~kg}$} \\
\hline Buying price/kg & \multicolumn{2}{|c|}{ Interest rate } & \multicolumn{3}{|c|}{$=10.0 \%$ annual } \\
\hline Initial weight ( $\mathrm{kg}$ ) & \multicolumn{2}{|c|}{ Wage rate/hr } & \multicolumn{3}{|c|}{$=\$ 2.85$ hour } \\
\hline Mortality rate & \multicolumn{2}{|c|}{ Fringe benefits } & $=16.0 \%$ & & \\
\hline
\end{tabular}

\section{Conclusions}

The selection of a high or low fertilization level system for meat production and its corresponding stocking rate cannot be made independently of the economic considerations. Factors such as the animal purchase and selling prices, not frequently considered for stocking rate and fertilization level recommendations, play a major role in the determination of which fertilization system offers the best opportunity to maximize income.

The above analyses suggest that under the present price levels, and for as long as the price spread between animal purchase and selling prices remains as high as those prevailing at the conclusion of the study, the system that offers the best possibilities of returns is that of low fertilization. Under the present conditions the stocking rate should be close to 3.8 animals per hectare -3.6 animals per hectare if a $454 \mathrm{~kg}$ finishing weight is required-and a 10- to 11-month grazing period. The high fertilization system returns were lower and are more affected by changes in fertilizer price, wage rates, and interest rates than the low 
fertilization, thus increasing the risk of not attaining the expected income. Moreover, since the initial investment per hectare for the operation of the high fertilization system is much higher than for the low, the former should not be selected unless its expected return is high enough to justify the additional risk.

\section{LITERATURE (ITED}

1. Caro-Costus, R., F. Abruña and J. Vicente-Chandler, 1976. Effect of three levels of fertilization on the productivity of Stargrass pastures growing on a steep Ultisol in the humid mountain region of Puerto Rico, $J$. Agrie. Univ. P.R. 60(2): 172-178.

2. - F. Abruna and J. Figarella, 1972. Effect of nitrogen rates, harvest interval and cutting heights on yield and composition of Stargrass in Puerto Rico. J. Agric. Univ. P.R. 56(3): 267-279.

3. - $\longrightarrow$ and 3 . Vicente-Chandler, 1981. Effect of three grazing intervals on carrying capacity and weight gains produced by Stargrass pastures, J. Agric. Univ. P.R. 65(1): $14-20$.

4. _-....., and F. Abruña, 1979. Comparison of heavily fertilized Congo, Star and Pangola grass pastures in the humid mountain region of Puerto Rico, J. Agric. Univ. P.R. $60(2): 179-185$.

5. _ _ - , and — 1972. Effect of four levels of fertilization on beef production and carrying capacity of pangola grass pastures in the humid mountain region of Puerto Rico. I. Agric. Univ. P.R. 56(3): 219-222.

6. Hildreth, R. J., and M. E. Riewe, 1963. Grazing production curves II. Determining the economic optimum stocking rate. Agron. J. 55: 370-372.

7. Jones, R. J. and R. L. Sandland, 1974. The relation between animal gain and stocking rate: Derivation of the relation from the results of grazing trials. $J$. Agric. Sci. Camb. 83: $335-342$.

8. National Oceanic and Atmospheric Administration, Climatological Data for Puerto Rico and the Virgin Islands, Vol. 28, No. 13, 1982.

9. Parch, L. D. and L. Allen-Torxel, 1989. Economic considerations in grazing research. p. 109-125. In: Grazing Research: Design, Methodology, and Analysis. Crop Science Society of America, Special Pub. No. 16, Madison, Wl.

10. Riewe, M. E., 1961. Use of the relationship of stocking rate to gain of cattle in an experimental design for grazing trials. Agron. J. 53: 309-313.

11. - J. C. Smith, J. H. Jones and E. C. Holt, 1963. Grazing production curves 1. Comparison of steer gains on Gulf ryegrass and tall fescue. Agron. J. 55: 367-369.

12. Vicente-Chandler, J., F. Silva, F. Abruña and J. A. Rodriguez, 1972. Effect of two cutting heights, four harvest intervals and five nitrogen rates on yield and composition of Congo grass under humid tropical conditions. J. Agric. Univ. P.R. 56(3): 280-291. 